\title{
Introducing the brief version of the Dysfunctional Attitude Scale (DAS-14) based on a large clinical sample
}

\author{
DÓRA PERCZEL-FORINTOS ${ }^{1}$ - VERONIKA MÉSZÁROS² - \\ BARBARA KULIG ${ }^{1}$ - DÓRA ANTAL-URAM ${ }^{1}$ - SÁNDOR RÓZSA ${ }^{2,3 *}$ \\ ${ }^{1}$ Department of Clinical Psychology, Semmelweis University, Budapest, Hungary \\ ${ }^{2}$ Károli Gáspár University of the Reformed Church in Hungary, Budapest, Hungary \\ ${ }^{3}$ Department of Psychiatry, Washington University School of Medicine, St. Louis, USA
}

(Received: 1 October 2020, accepted: 15 June 2021)

Theoretical background: The Dysfunctional Attitude Scale (DAS) is a measurement tool that is commonly used to detect dysfunctional beliefs contributing to the emergence and onset of depressive symptoms. Although it has been primarily used for testing clinical populations, and various forms of the scale have been created, only a small body of literature has proved its psychometric adequacy on a clinical sample. Goals: Therefore, the current study aims to construct an updated, reliable and brief version of the DAS. Methods: For this purpose, besides the normal samples of adolescents $(n=195)$ and adults $(n=270)$, a heterogeneous clinical sample $(n=1077)$ was involved in cross-sectional research. Results: The overall results of parallel analysis and exploratory factor analysis suggested a bifactor structure with a general factor and three extracted subfactors (Dependence, Perfectionism and Entitlement), comprising 14 items altogether $\left(\chi^{2}=157.26, \mathrm{DF}=63\right.$, $p<0.001, \mathrm{CFI}=0.970$, TLI $=0.957$, RMSEA $\left.=0.036, \mathrm{RMSEA} \mathrm{CI}_{90}=0.029-0.044\right)$. Convergent validity was tested by correlations with Beck Depression Inventory $(r=0.36, p<0.001)$. Conclusion: Our study was based on the largest clinical sample in the field of psychometric analysis of the DAS so far. The findings suggest that DAS14 as a brief version of the original DAS has good psychometric properties, and it can be widely used as a measurement tool in the assessment of mood disorders.

Keywords: Dysfunctional Attitude Scale, DAS14, brief version, large clinical sample, bifactor analysis, validity

\section{Introduction}

Attitudes are one of the core structures of the human cognitive system which help to categorise and interpret experiences in the mind (Beck, 1967). They develop in interaction with the social environment while adjusting to individual needs, and are activated during frustration (Epstein, 1998).

\footnotetext{
* Correspondence: Dr. Sándor Rózsa, Károli Gáspár University of the Reformed Church in Hungary, Faculty of Humanities and Social Sciences, Institute of Psychology, H-1037, Budapest, Bécsi út 324. E-mail: rozsa.sandor@kre.hu
} 
As generally present cognitive constructions in humans, attitudes influence thoughts, emotions and behavior. They may become dysfunctional while maladaptive patterns of reactions occur and perpetuate when encountering environmental stimuli, resulting in incapability to mobilise resources in order to maintain optimal functioning. Dysfunctional attitudes are overgeneralised, inconsistent, unrealistic beliefs organized into a continuum regarding the individual's self, the world and the future (Beck, Rush, Shaw, \& Emery, 1979). Appearing in mentally healthy individuals as well as in people with diagnosed mental disorders (i.e. depression and anxiety disorders), they develop during adapting to stressful life events. Extensive research investigating depression found that dysfunctional attitudes are not only maintaining/covarying factors of depressive symptoms, but also predictors of depressive relapse and predictors of depressive episode frequency (Brouwer, Williams, Forand, DeRubeis, \& Bockting, 2019; Ingram, Miranda, \& Segal, 1998; Scher, Ingram, \& Segal, 2005; Scotte, 1995; Thase \& Simons, 1992; Theasdal \& Dent, 1987). Therefore, measuring dysfunctional attitudes is also a clinically relevant question.

In contrast with the majority of questionnaires assessing dysfunctional attitudes and beliefs that target specific problems - such as sleep (Dysfunctional Attitudes and Beliefs about Sleep; Morin, Vallières, \& Ivers, 2007) or sexuality (Sexual Dysfunctional Beliefs Questionnaire; Nobre, Gouveia, \& Gomes, 2003) -, dysfunctional attitudes are measured in a wider sense by the Dysfunctional Attitude Scale (DAS). The 40-item DAS, as a widely accepted and applied questionnaire, was developed by Arlene Nancy Weissman (1979) and was completed by graduates and undergraduates. An initial, item-pool version of the DAS contained a hundred, 7-point Likert scale items in order to create two parallel forms that measure the distinctive characteristics of depressive cognitions. Applying principal component analysis with varimax rotation to form the structure of the questionnaire, Weissman found ten factors but used only one global dimension, as the aim of the study was to identify a general vulnerability factor to depression. As a result of empirical decisions, the DAS-A and the DAS-B comprising of 40 items and one general factor each, seemed psychometrically relevant, of which DAS form A remained the most widely applied version in clinical practice and depression research (e.g. Fuhr, Reitenbach, Kraemer, Hautzinger, \& Meyer 2017; Senormanci et al., 2014). Since the DAS-A has become a common measurement tool to monitor cognitive therapeutic processes, a considerable amount of research has been carried out in several countries that proved the validity and reliability of the DAS in other languages (e.g. Ohrt \& Thorell, 1998; Power et al., 1994; Sahin \& Sahin, 1992).

Although the 100-item DAS was developed to assess pathogenic features of mental disorders, Weissman's assessments were performed on a 
normative sample. Therefore, the factor structure of the DAS was revised by Beck, Brown, Steer and Weissman (1991) recruiting a large community of 2023 psychiatric outpatients. As a result, 9 factors were unfolded including 66 items. These factors were Vulnerability, Need for Approval, SuccessPerfectionism, Need to Please Others, Imperatives, Need to Impress, Avoidance of Appearing Weak, Control Over Emotions, Disapproval-Dependence, which vary from the unidimensional conception of Weissman (1979).

Synthetizing previous research and practice, Kopp (1994) introduced a 35item version of the questionnaire developed by Burns (1980). Burns (1980) transposed the original functional items into dysfunctional statements, resulting in 35 items collected from the DAS displaying dysfunctional beliefs, whereas Weissman and Beck (1978) also used reversely coded items (e.g. in the 35-items DAS item 6: 'I cannot find happiness without being loved by another person.' is composed in DAS-A in item 40: 'I can find happiness without being loved by another person.'). Based on Burns's theoretical model, compared to the DAS-A, no sum score is calculated; in contrast, seven subscales represent seven dysfunctional attitudes (Need for Approval, Love, Achievement, Perfectionism, Entitlement, Omnipotence, Autonomy) with total scores ranging from -10 to 10 .

Contributing to the reduction of items, a growing differentiation of psychometric methodology, patient fitting problems and redundancy of items resulted in attempts to shorten the questionnaire.

\subsection{Shortened forms of the DAS}

In the last decades, several studies were published about shortened versions of the DAS-A in order to increase patient compliance, reduce assessment and administration time. Explorative and confirmative factor-analyses of the questionnaire brought about heterogeneous results. Studies mainly have found a one factor solution (Beevers, Strong, Meyer, Pilkonis, \& Miller 2007; Ebrahimi, Samouei, Mousavii, \& Bornamanesh, 2012; Moore, Fresco, Segal, \& Brown, 2014). Other studies identified two (Batmaz \& Ozdel, 2016; de Graaf, Roelofs, \& Huibers, 2009; Mukhtar \& Oei, 2010; Ruiz et al., 2015a,b), three (Power et al., 1994; Tajima et al., 2007) or four factors of the DAS (Chioqueta \& Stiles, 2004). Further psychometric analyses, removed items from the original 100-item DAS or the 40-item DAS-A, resulted in 9-, 26- and 24-item forms of the questionnaire (Beevers et al. 2007; Ebrahimi et al., 2012; Power et al., 1994). Finally, a 17-item form of the DAS-R with two subscales (Perfectionism and Dependency) and a general factor became the most widespread version (de Graaf et al., 2009; Ruiz et al., 2015a,b) (See Table 1). 
These mixed results may presumably depend on the features of the obtained population due to cultural diversity (as is the case in the abbreviated versions from Norway, the Netherlands, Iran, Spain, Turkey, Malaysia), sample size and the examination of healthy or clinical samples, the different forms of the questionnaire and the different number of items. Additionally, the use of exploratory and confirmatory factor analyses might have led to different structures of the questionnaire. While exploratory factor analysis gives the possibility for researchers to decide the number of extracted factors, confirmatory factor analysis fit indices are more accurate, but at the same time they rely on a priori findings that limit the number of examined factors. Despite the heterogeneity of the obtained results, Perfectionism, Dependency and DAS total score seemed to remain constant factors, independent of the above mentioned influences.

Psychometric studies of DAS have yielded results of reliability and various forms of validity. Internal consistency of the 40-item general DAS and its subscales were at a range of 0.60-0.92 not only in the original English version but also in other languages (e.g. Ohrt \& Thorell, 1998; Power et al., 1994; Weissman, 1979). Test-retest reliability of the 24-item Japanese DAS with intraclass correlation (ICC) was relatively high $(0.79$, CI 95\% $=0.63-0.88)$ and the concurrent validity was also in the acceptable range with the Irrational Belief Test $(r=0.76, p<0.001$; Tajima et al., 2007). One study tested the predictive validity of the 40-item DAS-A using posttreatment Beck Depression Inventory (BDI) score. Beevers and his coworkers (2007) have found that the predictive value of the test is relatively small regarding depressive symptoms after cognitive therapy $(\beta=0.18, p=0.02)$ (with the control of pretreatment $\mathrm{BDI}$ ). According to convergent validity studies, the relationship between depressive symptoms and dysfunctional attitudes remains unassured. Medium level correlation has been found between different forms of the DAS and the BDI: DAS-A and BDI $(r=0.47, p<0.001$; Chioqueta \& Stiles, 2004); DAS-R and BDI $(r=0.37, p<0.001$; Batmaz \& Ozdel, 2016). Strong correlation has been obtained between BDI-II and DAS-24 (non-clinical sample: $r=0.44$, $p<0.001$; clinical sample: $r=0.63, p<0.001$; Tajima et al., 2007), the Malay revised form of the DAS and BDI on a heterogeneous clinical and non-clinical sample $(r=0.68, p<0.001$; Muhktar \& Oei, 2010).

Convergent validity of different forms of the DAS confirmed strong relationship with the Automatic Thoughts Questionnaire $(r=0.51, p<0.001$; Muhktar \& Oei, 2010), the General Health Questionnaire $(r=0.56, p<0.001$; Ebrahimi et al., 2012) and the Beck Hopelessness Scale $(r=0.51, p<0.001$; Batmaz \& Özdel, 2016), which reflect that dysfunctional attitudes are also in close relationship with the general cognitive system.

To conclude, based on correlational studies, the factor structure of the DAS does not show a consistent picture. In this context, the present study aims to (1) develop a brief and psychometrically reliable version of the DAS and (2) analyze its convergent and construct validity. 


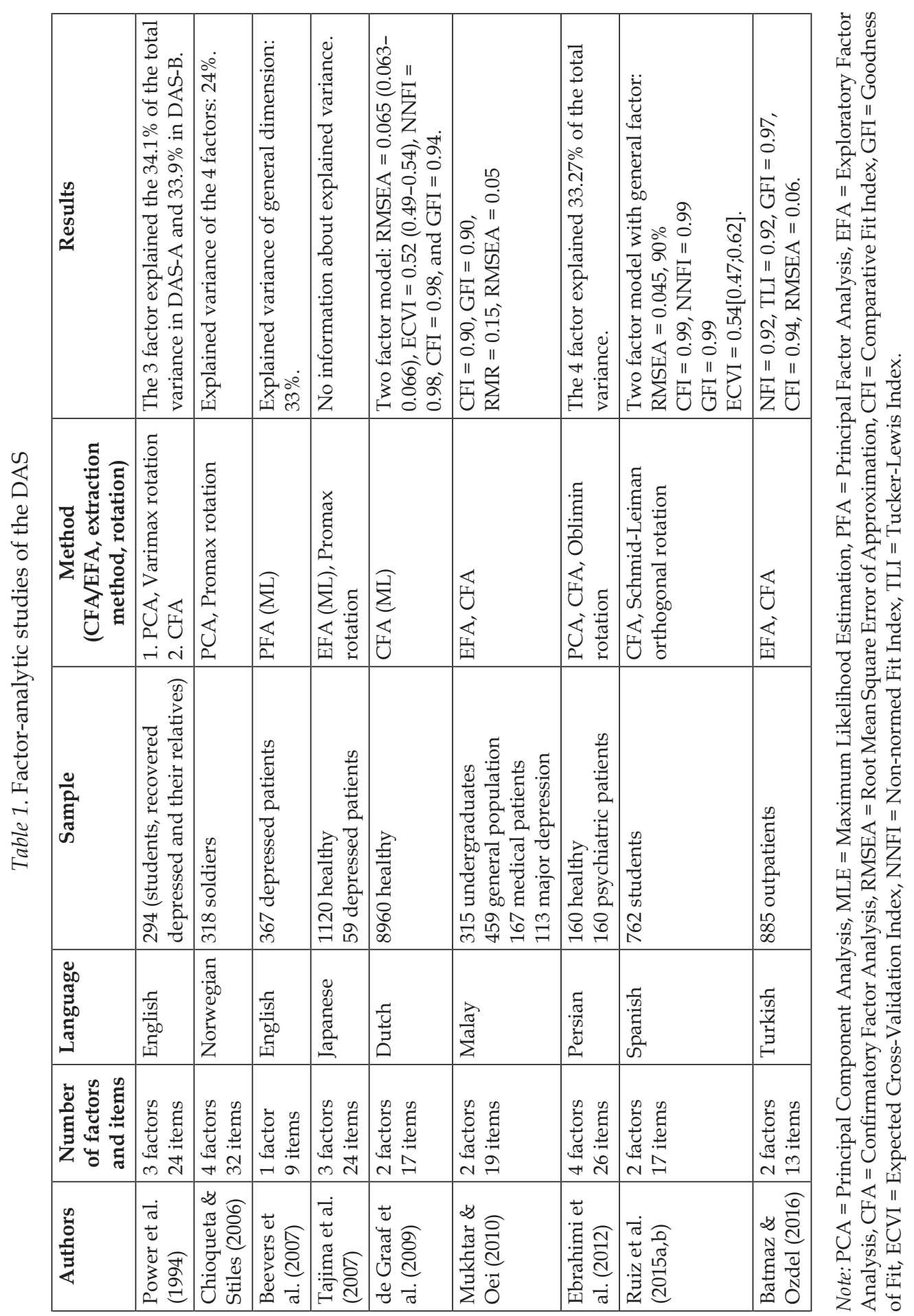




\section{Methods}

\subsection{Participants and procedures}

One clinical, one non-clinical and an adolescent group participated in the research, 1542 subjects altogether. The first group consisted of 1077 adult outpatients $(69.5 \%$ female, $M=34.2$ years, $S D=11.8$ years) who were referred for treatment to the mental health center of Semmelweis University Department of Clinical Psychology. Inclusion criteria were 18-65 years of age and at least one of the following mental disorders: major depression, different types of anxiety disorder, personality disorder, obsessive compulsive disorder, eating disorder, sleeping disorder and sexual dysfunction (Table 2). Exclusion criteria were acute psychosis, acute alcohol or drug use, mental retardation and dementia. Patients took part in a pretreatment diagnostic assessments conducted by a clinical psychologist or intern clinical psychologist. Diagnoses based on the ICD-10 (WHO, 2004) were established by a clinical interview, SCID-I, SCID-II and self-report questionnaires.

The subjects of the non-clinical group were recruited via internet from the general population $(n=270,77.4 \%$ female, $M=29.0$ years, $S D=9.5$ years). The adolescent sample comprised of 195 secondary school students (84.1\% female, $M=15.1$ years, $S D=0.90$ years), from a secondary school in Pest and Veszprém county.

Data of the clinical sample were collected at the mental health center; subjects from the non-clinical group were assessed via internet, while the adolescents completed the questionnaires during classes after parental consent. The study protocol was approved and reviewed by the regional and institutional ethics board of the collaborating institutions (ethical approval numbers of the study are: SE 194/2012; KRE: 53/2019/P/ET).

Prior to questionnaire completion, informed consent was given by participants providing voluntary and anonymous participation. No monetary reimbursement was given for the assessment (Table 2). 
Table 2. Sociodemographic data of clinical and non-clinical samples

\begin{tabular}{|c|c|c|}
\hline Variables & $\begin{array}{l}\text { Clinical } \\
\text { sample } \\
(n=1077)\end{array}$ & $\begin{array}{c}\text { Non-clinical } \\
\text { sample } \\
(n=270)\end{array}$ \\
\hline \multicolumn{3}{|l|}{ Marital status } \\
\hline Single & $434(40 \%)$ & $82(30 \%)$ \\
\hline In relationship & $312(29 \%)$ & $138(51 \%)$ \\
\hline Married & $232(22 \%)$ & $43(16 \%)$ \\
\hline Divorced & $64(5.9 \%)$ & $5(1.8 \%)$ \\
\hline Widow & $13(1.2 \%)$ & $2(0.7 \%)$ \\
\hline \multicolumn{3}{|l|}{ Socioeconomic status } \\
\hline Student & $247(23 \%)$ & $83(31 \%)$ \\
\hline Employed & $623(58 \%)$ & $151(56 \%)$ \\
\hline Unemployed/occupational disability & $186(17 \%)$ & $36(13 \%)$ \\
\hline \multicolumn{3}{|l|}{ Level of education } \\
\hline Elementary school & $93(8.6 \%)$ & $2(0.7 \%)$ \\
\hline High school/vocational school & $527(49 \%)$ & $84(31 \%)$ \\
\hline University/college & $443(41 \%)$ & $184(68 \%)$ \\
\hline \multicolumn{3}{|l|}{ Diagnoses (DSM-5) } \\
\hline Depressive disorders & $255(24 \%)$ & \\
\hline Anxiety disorders & $418(39 \%)$ & \\
\hline Bipolar and related disorders & $14(1 \%)$ & \\
\hline Obsessive-Compulsive and Related Disorders & $31(3 \%)$ & \\
\hline Trauma- and stressor-related disorders & $185(17 \%)$ & \\
\hline Personality disorders & $80(7 \%)$ & \\
\hline Somatic symptoms and related disorders & $49(5 \%)$ & \\
\hline Sleep-wake disorders & $6(0.6 \%)$ & \\
\hline Feeding and eating disorders & $18(2 \%)$ & \\
\hline Substance-related and addictive disorders & $9(0.8 \%)$ & \\
\hline Sexual dysfunctions & $3(0.2 \%)$ & \\
\hline $\begin{array}{l}\text { Schizophrenia spectrum and other related } \\
\text { disorders }\end{array}$ & $9(0.8 \%)$ & \\
\hline
\end{tabular}




\subsection{Measurements}

Sociodemographic data. As for the clinical sample, age, sex, socioeconomic status, highest level of education and marital status were assessed during the first clinical interview. Questions regarding sociodemographic data of the non-clinical sample were administered via internet. Sociodemographic data of the adolescent sample was collected by paper-and-pencil assessment.

Dysfunctional Attitude Scale (DAS). In the current study, the 35-item version of the DAS was administered in all samples (Kopp, 1994; Weissman \& Beck, 1978). Items were scored on a 5-point Likert scale $(-2=$ Absolutely agree to $2=$ Absolutely disagree) resulting in a total score between -70 and 70 . Seven subscales are assumed to exist, with 5 items in each subscale (Need for Approval, Seeking Love, Performance Evaluation, Perfectionism, Entitlement, Omnipotence, Autonomy), with results ranging from -10 to 10 each. A higher total score represents more frequent activation of the dysfunctional attitudes. Internal consistency of the subscales ranged from 0.57 to 0.79 in previous studies (Mészáros et al., 2014).

Beck Depression Inventory (BDI). The Beck Depression Inventory (BDI, Beck, Ward, Mendelson, Mock, \& Erbaugh, 1961; Kopp \& Fóris, 1993) contains 21 items measuring the severity of emotional, motivational, cognitive and somatic symptoms of depression. Each item consists of four statements with varying severity of one particular symptom. Total scores range from 0 to 63 with higher scores reflecting more severe depression. In the present study, Cronbach's $\alpha$ of the BDI confirmed previously assessed excellent reliability (0.90) by Mészáros et al. (2014).

\subsection{Statistical analysis}

To evaluate the factor structure of the DAS-R, an exploratory factor analysis (EFA) was first performed to explore the factor structure on the clinical sample. Prior to conducting the EFA, the Kaiser-Meyer-Olkin measure of sampling adequacy (KMO) and Bartlett's test of sphericity were used to check for the factorability of the data. We decided on the number of factors using parallel analysis based on a polychoric correlation matrix when performing the EFA (Timmerman \& Lorenzo-Seva, 2011). The CFA was applied to confirm the factor structure we extracted in the EFA with maximum likelihood estimation with the clinical, non-clinical and adolescent samples. The following indices were used to evaluate how well the data fit the model: Chi-Square value, degrees of freedom (DF), root mean square error of approximation (RMSEA $<0.08)$, comparative fit index $(\mathrm{CFI}<0.90)$, and Tucker-Lewis index (TLI > 0.90) (Bentler, 1990). 
We also calculated the percent of Explained Common Variance (ECV; Reise, Moore, \& Haviland, 2010), an index of unidimensionality, attributable to the general factor and each of the three group factors. When Percent of Uncontaminated Correlations (PUC) values are higher than 0.80 , general ECV values are less important in predicting bias; when PUC values are lower than 0.80, general ECV values greater than 0.60 and Coefficient Omega Hierarchical values greater than 0.70 suggest that the presence of multidimensionality is not severe enough to disqualify the interpretation of the instrument as primarily unidimensional (Reise, Scheines, Widaman, \& Haviland 2013). In turn, group factor ECVs establish the uniqueness of each factor, with a low group ECV indicating little unique variability due to that subscale factor.

We also tested convergent validity with Beck Depression Inventory. Parson correlation was used to test the convergence.

We used Amos, SPSS 27.0 and FACTOR 10.10.03. for statistical analyses.

\section{Results}

\subsection{Exploratory factor analyses (EFA) with clinical sample}

The EFA was first used to analyze the data and identify the underlying factors of all 35 items for clinical sample. The KMO value was 0.92 , which was higher than the recommended value of 0.60 . The Bartlett's test of sphericity $\left(\chi^{2}=9623.41, p<0.001\right)$ was adequate, which implied that the data of the clinical sample were suitable for factor analysis. Parallel analysis confirmed a three-factor model of DAS-R. The EFA with varimax rotation extracted a three-factor solution that accounted for $32.3 \%$ of the total variance. Several items did not load onto any of the extracted factors, and few of them demonstrated high cross-loading for another factor (Table 3). Factors 1, 2, and 3 (F1, F2 and F3) were named Performance Evaluation and Perfectionism, Entitlement, and Seeking Love, respectively. 
Table 3. Factor loadings, communalities $\left(h^{2}\right)$, percentage of extracted variance accounted by for each factor based on Exploratory Factor Analysis (EFA) and Varimax rotation

\begin{tabular}{|c|c|c|c|c|}
\hline Subscales and items & F1 & F2 & F3 & $h^{2}$ \\
\hline \multicolumn{5}{|l|}{ Need for Approval } \\
\hline $\begin{array}{l}\text { 1. Criticism will obviously upset the person who receives } \\
\text { the criticism. }\end{array}$ & & & & 0.19 \\
\hline $\begin{array}{l}\text { 2. It is best to give up my own interests in order to please } \\
\text { other people. }\end{array}$ & 0.44 & & & 0.29 \\
\hline 3. I need other people's approval in order to be happy. & 0.33 & & 0.57 & 0.43 \\
\hline $\begin{array}{l}\text { 4. If someone important to me expects me to do } \\
\text { something, then I really should do it. }\end{array}$ & & & & 0.07 \\
\hline $\begin{array}{l}\text { 5. My value as a person depends greatly on what others } \\
\text { think of me. }\end{array}$ & 0.45 & & 0.48 & 0.47 \\
\hline \multicolumn{5}{|l|}{ Seeking Love } \\
\hline $\begin{array}{l}\text { 6. I cannot find happiness without being loved by } \\
\text { another person. }\end{array}$ & & & 0.69 & 0.51 \\
\hline 7. If others dislike you, you are bound to be less happy. & & & 0.75 & 0.58 \\
\hline $\begin{array}{l}\text { 8. If people whom I care about reject me it means there is } \\
\text { something wrong with me. }\end{array}$ & & & 0.49 & 0.30 \\
\hline $\begin{array}{l}\text { 9. If a person I love does not love me, it means I am } \\
\text { unlovable. }\end{array}$ & 0.56 & & 0.38 & 0.48 \\
\hline $\begin{array}{l}\text { 10. Being isolated from others is bound to lead to } \\
\text { unhappiness. }\end{array}$ & & & 0.46 & 0.22 \\
\hline \multicolumn{4}{|l|}{ Performance Evaluation } & 0.51 \\
\hline $\begin{array}{l}\text { 11. If I am to be a worthwhile person, I must be truly } \\
\text { outstanding in at least one major respect. }\end{array}$ & 0.58 & & 0.30 & 0.41 \\
\hline $\begin{array}{l}\text { 12. I must be a useful, productive, creative person, or life } \\
\text { has no purpose. }\end{array}$ & 0.47 & & & 0.29 \\
\hline $\begin{array}{l}\text { 13. People who have good ideas are more worthy than } \\
\text { those who do not. }\end{array}$ & 0.65 & & & 0.43 \\
\hline $\begin{array}{l}\text { 14. If I do not do as well as other people, it means I am } \\
\text { inferior. }\end{array}$ & 0.73 & & & 0.58 \\
\hline 15. If I fail at my work, then I am a failure as a person. & 0.68 & & & 0.51 \\
\hline \multicolumn{5}{|l|}{ Perfectionism } \\
\hline $\begin{array}{l}\text { 16. If you cannot do something well, there is little point } \\
\text { in doing it at all. }\end{array}$ & 0.57 & & & 0.32 \\
\hline 17. It is shameful for a person to display his weaknesses. & 0.58 & & & 0.35 \\
\hline $\begin{array}{l}\text { 18. A person should try to be the best at everything he } \\
\text { undertakes. }\end{array}$ & 0.38 & 0.31 & & 0.28 \\
\hline 19. I should be upset if I make a mistake. & 0.34 & & 0.33 & 0.22 \\
\hline $\begin{array}{l}\text { 20. If I don't set the highest standards for myself, } \\
\text { I am likely to end up a second rate person. }\end{array}$ & 0.69 & & & 0.48 \\
\hline
\end{tabular}


Table 3. (Continued)

\begin{tabular}{|c|c|c|c|c|}
\hline Subscales and items & F1 & F2 & F3 & $h^{2}$ \\
\hline \multicolumn{5}{|l|}{ Entitlement } \\
\hline $\begin{array}{l}\text { 21. If I strongly believe I deserve something, } \\
\text { I have a reason to expect that I should get it. }\end{array}$ & & 0.48 & & 0.23 \\
\hline $\begin{array}{l}\text { 22. It is necessary to become frustrated if you find } \\
\text { obstacles to getting what you want. }\end{array}$ & & 0.48 & & 0.26 \\
\hline $\begin{array}{l}\text { 23. If I put other people's needs before my own, they } \\
\text { should help me when I need something from them. }\end{array}$ & & 0.64 & & 0.43 \\
\hline $\begin{array}{l}\text { 24. If I am a good husband (or wife), then my spouse is } \\
\text { bound to love me. }\end{array}$ & & 0.67 & & 0.45 \\
\hline $\begin{array}{l}\text { 25. If I do nice things for someone, I can anticipate that } \\
\text { they will respect me and treat me just as well as I treat } \\
\text { them. }\end{array}$ & & 0.61 & & 0.35 \\
\hline \multicolumn{5}{|l|}{ Omnipotence } \\
\hline $\begin{array}{l}\text { 26. I should assume responsibility for how people feel } \\
\text { and behave if they are close to me. }\end{array}$ & & & & 0.08 \\
\hline $\begin{array}{l}\text { 27. If I criticize the way someone does something and } \\
\text { they become angry or depressed, this means I have } \\
\text { upset them. }\end{array}$ & 0.34 & & & 0.22 \\
\hline $\begin{array}{l}\text { 28. To be a good, worthwhile, virtuous person, I must try } \\
\text { to help everyone who needs it. }\end{array}$ & & 0.39 & & 0.23 \\
\hline $\begin{array}{l}\text { 29. If a child is having emotional or behavioral } \\
\text { difficulties, this shows that the child's parents have } \\
\text { failed in some important respect. }\end{array}$ & 0.31 & & & 0.11 \\
\hline 30. I should be able to please everybody. & 0.53 & 0.39 & & 0.44 \\
\hline \multicolumn{5}{|l|}{ Autonomy } \\
\hline $\begin{array}{l}\text { 31. I cannot expect to control how I feel when something } \\
\text { bad happens. }\end{array}$ & & & 0.35 & 0.21 \\
\hline $\begin{array}{l}\text { 32. There is no point in trying to change upsetting } \\
\text { emotions because they are a valid and inevitable part } \\
\text { of daily life. }\end{array}$ & & & & 0.12 \\
\hline $\begin{array}{l}\text { 33. My moods are primarily created by factors that are } \\
\text { largely beyond my control, such as the past, or body } \\
\text { chemistry, or hormone cycles, or biorhythms, or } \\
\text { chance, or fate. }\end{array}$ & 0.34 & 0.32 & & 0.24 \\
\hline 34. My happiness largely depends on what happens to me. & & 0.45 & & 0.28 \\
\hline $\begin{array}{l}\text { 35. People who have the marks of success (good looks, } \\
\text { social status, wealth or fame) are bound to be happier } \\
\text { than those who do not. }\end{array}$ & 0.42 & & & 0.26 \\
\hline Percentage of the variance & 22.08 & 5.51 & 4.74 & - \\
\hline
\end{tabular}

Note: clinical sample $(n=1077)$. Factor $1=$ Performance Evaluation and Perfectionism, Factor 2 = Entitlement, Factor 3 = Seeking Love. 


\subsection{Confirmatory factor analyses (CFA) with clinical, non-clinical and adolescent samples}

The internal structure of the 35-item DAS and DAS-14 was tested via a series of CFAs (with MLR method, and oblique rotation) specifically. For the 35-item original version, the one- and seven-factor second order versions were tested, respectively. The abbreviated 14-item version was tested in a one-factor form, and also the three-factor, and bifactor form based on previous exploratory factor analysis.

Regarding the DAS-14, both the bifactor and the three-factor solutions demonstrated adequate model fit for every sample (Table 4). The original DAS-R unidimensional and seven-factor solutions had inadequate model fit.

Table 4. Goodness of fit statistics for all tested measurement models

\begin{tabular}{|c|c|c|c|c|c|c|}
\hline Model & $\chi^{2}$ & DF & $p$ & $\begin{array}{l}\text { RMSEA } \\
\left(\mathrm{CI}_{90}\right)\end{array}$ & CFI & TLI \\
\hline \multicolumn{7}{|l|}{ Clinical sample $(n=1077)$} \\
\hline Unidimensional (DAS-35) & 3166.22 & 560 & $<0.001$ & $\begin{array}{l}0.064 \\
(0.061- \\
0.066)\end{array}$ & 0.720 & 0.703 \\
\hline $\begin{array}{l}\text { Seven-factor second order } \\
\text { (DAS-35) }\end{array}$ & 1822.74 & 539 & $<0.001$ & $\begin{array}{l}0.046 \\
(0.044- \\
0.048)\end{array}$ & 0.859 & 0.845 \\
\hline Unidimensional (DAS-14) & 1072.59 & 77 & $<0.001$ & $\begin{array}{l}0.107 \\
(0.101- \\
0.113)\end{array}$ & 0.686 & 0.628 \\
\hline $\begin{array}{l}\text { Three-factor second order } \\
\text { (DAS-14) }\end{array}$ & 208.61 & 74 & $<0.001$ & $\begin{array}{l}0.040 \\
(0.034- \\
0.047)\end{array}$ & 0.957 & 0.948 \\
\hline $\begin{array}{l}\text { Three-factor bifactor } \\
\text { (DAS-14) }\end{array}$ & 157.26 & 63 & $<0.001$ & $\begin{array}{l}0.036 \\
(0.029- \\
0.044)\end{array}$ & 0.970 & 0.957 \\
\hline \multicolumn{7}{|c|}{ Non-clinical sample $(n=270)$} \\
\hline Unidimensional (DAS-35) & 1356.76 & 560 & $<0.001$ & $\begin{array}{l}0.073 \\
(0.068- \\
0.078)\end{array}$ & 0.657 & 0.636 \\
\hline $\begin{array}{l}\text { Seven-factor second order } \\
\text { (DAS-35) }\end{array}$ & 1010.91 & 539 & $<0.001$ & $\begin{array}{l}0.057 \\
(0.052- \\
0.062)\end{array}$ & 0.797 & 0.776 \\
\hline
\end{tabular}




\begin{tabular}{|c|c|c|c|c|c|c|}
\hline Model & $\chi^{2}$ & DF & $p$ & $\begin{array}{c}\text { RMSEA } \\
\left(\mathrm{CI}_{90}\right)\end{array}$ & CFI & TLI \\
\hline Unidimensional (DAS-14) & 397.78 & 77 & $<0.001$ & $\begin{array}{l}0.124 \\
(0.112- \\
0.137)\end{array}$ & 0.625 & 0.557 \\
\hline $\begin{array}{l}\text { Three-factor second order } \\
\text { (DAS-14) }\end{array}$ & 142.77 & 74 & $<0.001$ & $\begin{array}{l}0.059 \\
(0.044- \\
0.073)\end{array}$ & 0.920 & 0.901 \\
\hline $\begin{array}{l}\text { Bifactor with three } \\
\text { specific factors (DAS-14) }\end{array}$ & 100.31 & 63 & 0.002 & $\begin{array}{l}0.047 \\
(0.029- \\
0.064)\end{array}$ & 0.956 & 0.937 \\
\hline \multicolumn{7}{|l|}{ Adolescent sample $(n=195)$} \\
\hline Unidimensional (DAS-35) & 822.73 & 560 & $<0.001$ & $\begin{array}{l}0.049 \\
(0.042- \\
0.056)\end{array}$ & 0.560 & 0.533 \\
\hline $\begin{array}{l}\text { Seven-factor second order } \\
\text { (DAS-35) }\end{array}$ & 709.51 & 539 & $<0.001$ & $\begin{array}{l}0.040 \\
(0.032- \\
0.048)\end{array}$ & 0.715 & 0.685 \\
\hline Unidimensional (DAS-14) & 183.34 & 77 & $<0.001$ & $\begin{array}{l}0.084 \\
(0.069- \\
0.100)\end{array}$ & 0.526 & 0.440 \\
\hline $\begin{array}{l}\text { Three-factor second order } \\
\text { (DAS-14) }\end{array}$ & 87.95 & 74 & 0.128 & $\begin{array}{l}0.031 \\
(0.000- \\
0.054)\end{array}$ & 0.938 & 0.923 \\
\hline $\begin{array}{l}\text { Bifactor with three } \\
\text { specific factors (DAS-14) }\end{array}$ & 68.21 & 63 & 0.305 & $\begin{array}{l}0.021 \\
(0.000- \\
0.049)\end{array}$ & 0.977 & 0.966 \\
\hline
\end{tabular}

Note: $\mathrm{DF}=$ degree of freedom, RMSEA = Root Mean Square Error of Approximation, CFI = Comparative Fit Index, TLI = Tucker-Lewis Index.

\subsection{Standardized loadings and model-based reliability estimates for the DAS-14}

Table 5 summarises the factor loadings for the unidimensional and bifactor solutions for the DAS-14. Most general factor item loadings were similar to the group factor loadings and to the item loadings from the unidimensional solution. The ECV coefficients for the DAS-14 were low. Eight of the 14 items had Individual Explained Common Variance (IECV) coefficients below 0.50, which indicated that most items were better measures of the group factors than the general factor. 
Coefficient Omega Hierarchical ( $\omega H$; McDonald, 1999) measures the proportion of total score variance that can be attributed to a single general factor after accounting for group (i.e., subscale) factors. Coefficient Omega Subscale $(\omega S)$ is a version of $\omega H$ that measures the proportion of subscale score variance that is uniquely due to that group (i.e., subscale) factor after controlling for the general factor. Thus, $\omega H=0.60$ would indicate that the DAS-14's total score predominantly reflects a single general factor despite the presence of multidimensionality across items, which in turn would permit researchers to interpret the total score as a sufficiently reliable and appropriate measure of the general construct of dysfunctional attitudes.

Table 5. Factor loadings for the unidimensional and bifactor solutions for the DAS-14

\begin{tabular}{|l|c|c|c|c|c|c|c|}
\hline Subscales and items & $\begin{array}{c}\text { Unidimensio- } \\
\text { nal model }\end{array}$ & \multicolumn{5}{|c|}{ Bifactor model } \\
\cline { 3 - 8 } & & $\begin{array}{c}\text { General } \\
\text { Factor } \\
\left(F_{\mathrm{g}}\right)\end{array}$ & $F 1$ & $F 2$ & $F 3$ & IECV \\
\hline Seeking Love & 0.43 & 0.48 & 0.56 & & & 0.42 \\
\hline DAS6 & 0.45 & 0.50 & 0.52 & & & 0.48 \\
\hline DAS7 & 0.43 & 0.50 & 0.12 & & & 0.95 \\
\hline DAS8 & 0.27 & 0.31 & 0.22 & & & 0.66 \\
\hline DAS10 & 0.66 & 0.49 & & 0.45 & & 0.54 \\
\hline Performance Evaluation and Perfectionism & & & & \\
\hline DAS13 & 0.78 & 0.56 & & 0.65 & & 0.42 \\
\hline DAS14 & 0.72 & 0.53 & & 0.53 & & 0.49 \\
\hline DAS15 & 0.46 & 0.37 & & 0.26 & & 0.66 \\
\hline DAS16 & 0.57 & 0.44 & & 0.36 & & 0.59 \\
\hline DAS20 & 0.26 & 0.24 & & & 0.37 & 0.31 \\
\hline Entitlement & 0.24 & 0.28 & & & 0.26 & 0.53 \\
\hline DAS21 & 0.34 & 0.37 & & & 0.55 & 0.30 \\
\hline DAS22 & 0.31 & 0.31 & & & 0.56 & 0.24 \\
\hline DAS23 & 0.24 & 0.25 & & & 0.49 & 0.21 \\
\hline DAS24 & & 0.83 & 0.67 & 0.79 & 0.67 & \\
\hline DAS25 & & 0.60 & 0.26 & 0.38 & 0.47 & \\
\hline Cronbach's $\alpha$ & 0.46 & 0.12 & 0.21 & 0.20 & \\
\hline Omega Hierarchical $(\omega H)$ & & & & & \\
\hline Explained Common \\
Variance (ECV) & & & & & \\
\hline
\end{tabular}




\subsection{Validity of the DAS-14}

To provide data on the convergent validity of the brief DAS-14, correlations between the DAS-14 scores and BDI were investigated on the clinical sample $(n=1077)$. As predicted, the 3 subscales and global DAS14 score were positively correlated with the BDI total score. We have found medium positive correlation with the global DAS-14 score $(r=0.36, p<0.001)$, Performance Evaluation and Perfectionism subscale $(r=0.41, p<0.001)$, and Entitlement subscale $(r=0.39, p<0.001)$. Low correlation was found with Seeking Love subscale $(r=0.27, p<0.001)$.

\section{Discussion}

The present study aims to revise the Dysfunctional Attitude Scale (DAS) in order to clarify its factor structure. Since the rate of dysfunctionality is arranged on a continuum, the current paper aimed to create a measurement tool in order to examine dysfunctional attitudes in mentally healthy population and among mental disorders. Wide range of applicability was taken into account when choosing items. In addition, keeping clinically relevant information served the purpose of facilitating its clinical application by a shortened version. Owing to bifactor solution, total score of the measure reflects the global intensity of dysfunctionality while subscales help to identify different problem areas.

Compared to the original 7 and 9 subscale forms of the DAS, in the present study we identified three dysfunctional attitudes, namely, Seeking Love, Performance Evaluation, and Entitlement. These are consistent with Beck's vulnerability theory describing that individuals categorise and structure their experiences by perception (Beck, et al., 1979). As perceptual schemas are damaged, maladaptive, over-generalised structures may distort cognitions by letting a depressive thinking pattern become dominant in cognitive processes. Dysfunctional attitudes evolving on the basis of maladaptive schemas can be measured by the DAS. Although numerous revised versions of the scale were developed, Perfectionism and Dependence/Seeking Love were recurringly confirmed to exist as stable factors (de Graaf et al., 2009; Ruiz et al., 2015a,b).

The current study is partly in accordance with previous findings, mainly by highlighting the significance of Perfectionism and Seeking Love. The depressive cognitive self-system - a core of Beck's concept - provides a basis for negative preconceptions about not only the self but also interpersonal relationships and about the future. These ideations are dividable into well-defined schemas, of which Unlovableness and Self- 
worthlessness are primal. Self-worthlessness is a core maladaptive schema of depressive self-experience with a drive to prove a person's value through talent and excellence; and Unlovableness operates the level of trust in people as well as the intensity of a desire to be loved (Beck et al., 1979; Tringer, 2007).

In DAS-14 the third dysfunctional attitude (the third factor) named Entitlement represents the expectations and frustrations toward others, such as in item \#23 "If I put other people's needs before my own, they should help me when I need something from them." It is in line with the negative view of the world in Beck's negative cognitive triad of depression (e.g. Genuchi \& Valdez, 2015; Kopp, Skrabski, \& Szedmák, 2000; Rude, Chrisman, Burton Denmark, \& Maestas, 2012).

Psychometric analyses considered not only factor content appropriateness, but also clinically relevant features of the DAS. Focusing on Beck's cognitive vulnerability concept, the present study applied three independent samples in order to maintain its theoretical qualities. Since the DAS is primarily a diagnostic measurement tool, another aim was to maintain comprehensibility, conciseness and clarity of the statements. Hence, two psychometrically weaker items \#8 and \#10 ("If people whom I care about reject me it means there is something wrong with me." and "Being isolated from others is bound to lead to unhappiness.") were kept in the questionnaire in order to strengthen the theoretical coherence of the scale.

The most remarkable result to emerge from the data is the fitting of the bifactor model, showing a clear advantage over balancing the psychometrical parameters and diagnostic properties including multidimensionality of the scale. The bifactor solution allows the use of a general factor in order to gain a holistic picture of the dysfunctionality level of cognitive processes. On the other hand, analyzing the three subscales of Seeking Love, Performance Evaluation and Perfectionism, and Entitlement separately may contribute to obtaining a more detailed and more specific picture about the problem areas of the patient (Brunner, Nagy, \& Wilhelm, 2012; Chen, West, \& Sousa, 2006).

Another noteworthy finding is the adequate construct validity of the DAS-14. Convergent validity of the brief DAS-14 was also confirmed by finding medium level correlations with the Beck Depression Inventory, supporting a previous study by Batmaz and Ozdel (2016).

A strength of the study, regarding sample size, is that this study has been carried out on the largest clinical sample in the field of psychometric analysis of the DAS so far. Sample heterogeneity and functional aspects required multiphasic analyses, thus, parallel and bifactor modelling were used. 
Settings of questionnaire completion differed by subgroups. While clinical subjects went under a diagnostic process with the control of a health professional, the adolescent sample filled in the form by paper-and-pencil testing in a group setting, and healthy subjects via internet. This could cause differences between groups. However, previous research found similar features of data collecting methods when contrasting paper-and-pencil scores with online assessment (i.e. Cronly et al., 2018; Vosylis, Zukauskiene, \& Malinauskiene, 2012). Moreover, the considerable gap between subgroup sizes could have influenced the obtained results. Sample size of the clinical population met factor analytic criteria. In contrast, adolescent and normal population sample sizes were not sufficient for conducting exploratory factor analysis properly. However, fitting of the bifactor model was fairly similar in all samples. Thus, our results are confined mainly to a clinical population with the supplementary role of normal and adolescent data.

On the other side, a limitation of the study is that various test batteries were given during assessments. Consequently, test priming effects also differed by subgroups. For instance, the clinical population completed depression and anxiety scales besides the DAS. Previous research supported the finding that monitoring depressive symptoms and anxiety may influence self-reported mood and negative mood priming might increase levels of dysfunctional attitudes (Fresco, Heimberg, Abramowitz, \& Bertram, 2006; Mark, Sinclair, \& Wellens, 1991). Consequently, an affective priming effect could cause differences in test results. Finally, since our data collecting method was cross-sectional, no test-retest reliability or predictive value was investigated. Research into solving this problem requires longitudinal design. Apart from structural validity, other types of validity should be investigated on normal population.

To summarise, our findings support that DAS-14 is an appropriate, reliable and valid questionnaire to be used in research and clinical practice. It can be used not only for diagnostic purposes but also for monitoring therapeutic effects along multidimensional scaling. In the present study, the brief DAS showed sufficient internal consistency with theoretically proven three factors, thus allowing for reduced administration time. All in all, the brief DAS-14 has several benefits compared to the original, longer forms.

\section{References}

Batmaz, S., \& Ozdel, K. (2016). Psychometric properties of the revised and abbreviated form of the Turkish version of the Dysfunctional Attitude Scale. Psychological Reports, 118(1), 180-198.

Beck, A. T. (1967). Depression: Clinical, experimental, and theoretical aspects. Philadelphia, PA: University of Pennsylvania Press 
Beck, A. T., Brown, G., Steer, R. A., \& Weissman, A. N. (1991). Factor analysis of the Dysfunctional Attitude Scale in a clinical population. Psychological Assessment, 3(3), 478-483.

Beck, A. T., Rush, A. J., Shaw, B. F., \& Emery, G. (1979). Cognitive therapy of depression. New York, NY: Guilford

Beck, A. T., Ward, C. H., Mendelson, M., Mock, J. \& Erbaugh, J. (1961) An inventory for measuring depression. Archives of General Psychiatry, 4, 561-571.

Beevers, C. G., Strong, D. R., Meyer, B., Pilkonis, P. A., \& Miller, I. W. (2007). Efficiently assessing negative cognition in depression: An item response theory analysis of the Dysfunctional Attitude Scale. Psychological Assessment, 19(2), 199-209.

Bentler, P. M. (1990). Comparative fit indexes in structural models. Psychological Bulletin, 107(2), 238-246.

Brouwer, M. E., Williams, A. D., Forand, N. R., DeRubeis, R. J., \& Bockting, C. L. H. (2019). Dysfunctional attitudes or extreme response styles as predictors of depressive relapse and recurrence after mobile cognitive therapy for recurrent depression. Journal of Affective Disorders 243, 48-54.

Brunner, M., Nagy, G., \& Wilhelm, O. (2012). A tutorial on hierarchically structured constructs. Journal of Personality, 80(4), 796-846.

Burns, D. D. (1980). Feeling good. The new mood therapy. New York, NY: New American Library

Chen, F. F., West, S. G., \& Sousa, K. H. (2006). A comparison of bifactor and second order models of quality of life. Multivariate Behavioral Research, 41(2), 189-225.

Chioqueta, A. P., \& Stiles, T. C. (2004). Psychometric properties of the Norwegian version of the Dysfunctional Attitude Scale (Form A). Cognitive Behaviour Therapy, 33(2), 83-86.

Cronly, J., Duff, A. J., Riekert, K. A., Perry, I. J., Fitzgerald, A. P., Horgan, A., et al. (2018). Online versus paper-based screening for depression and anxiety in adults with cystic fibrosis in Ireland: a cross-sectional exploratory study. BMJ Open, 8(1), e019305. DOI: 10.1136/bmjopen-2017-019305

de Graaf, E. L., Roelofs, J., \& Huibers, M. J. H. (2009). Measuring dysfunctional attitudes in the general population: The Dysfunctional Attitude Scale (form A) Revised. Cognitive Therapy and Research, 33, 345-355.

Ebrahimi, A., Samouei, R., Mousavii, S. G., \& Bornamanesh, A. R. (2012). Development and validation of 26-item dysfunctional attitude scale. Asia-Pacific Psychiatry, 5, 101-107.

Epstein, S. (1998). Cognitive-experiential self-theory. In M. Hersen, D. F. Barone, \& V. B. Van Hasselt (Eds.), Advanced personality (211-238). Boston, MA: Springer

Fresco, D. M., Heimberg, R. G., Abramowitz, A., \& Bertram, T. (2006). The effect of a negative mood priming challenge on dysfunctional attitudes, explanatory style, and explanatory flexibility. British Journal of Clinical Psychology, 45, 167-183.

Fuhr, K., Reitenbach, I., Kraemer, J., Hautzinger, M., \& Meyer, T. D. (2017). Attachment, dysfunctional attitudes, self-esteem, and association to depressive symptoms in patients with mood disorders. Journal of Affective Disorders, 212, 110-116.

Genuchi, M. C., \& Valdez, J. N. (2015). The role of anger as a component of a masculine variation of depression. Psychology of Men and Masculinity, 16(2), 149-159.

Ingram, R. E. (2003). Origins of cognitive vulnerability to depression. Cognitive Therapy and Research, 27, 77-88.

Ingram, R. E., Miranda, J., \& Segal, Z. V. (1998). Cognitive vulnerability to depression. New York, NY: Guilford Press

Kopp, M. (1994). Orvosi pszichológia. Az egészséglélektan és a magatartásorvoslás alapjai. Budapest: SOTE Magatartástudományi Intézet 
Kopp, M., \& Fóris, N. (1993). A szorongás kognitív viselkedésterápiája. Budapest: Végeken

Kopp, M., Skrabski, Á., \& Szedmák, S. (2000). Psychosocial risk factors, inequality and self-rated morbidity in a changing society. Social Science and Medicine, 51(9), 1351-1361.

Mark, M. M., Sinclair, R. C., \& Wellens, T. R. (1991). The effect of completing the Beck Depression Inventory on self-reported mood state: Contrast and assimilation. Personality and Social Psychology Bulletin, 17(4), 457-465.

McDonald, R. P. (1999). Test theory: A unified treatment. Mahwah, NJ: Erlbaum

Mészáros, V., Ajtay, Gy., Fodor, K. E., Komlósi, S., Boross, V., Barna, C., et al. (2014). Az életeseményektől a depressziós és szorongásos panaszokig: a diszfunkcionális attitúdök és a megküzdés szerepe a patogenezis folyamatában. Ideggyógyászati Szemle, 67(11-12), 397-408.

Moore, M. T., Fresco, D. M., Segal, Z. V., \& Brown, T. A. (2014). An exploratory analysis of the factor structure of the Dysfunctional Attitude Scale-Form A (DAS). Assessment, 21(5), 570-579.

Morin, C. M., Vallières, A., \& Ivers, H. (2007). Dysfunctional beliefs and attitudes about sleep (DBAS): Validation of a brief version (DBAS-16). Sleep, 30(11), 1547-1554.

Mukhtar, F., \& Oei, T. P. S. (2010). Exploratory and confirmatory factor validation of the Dysfunctional Attitude Scale for Malays (DAS-Malay) in Malaysia. Asian Journal of Psychiatry, 3, 145-151.

Nobre, P., Gouveia, J. P., \& Gomes, F. A. (2003). Sexual dysfunctional beliefs questionnaire: An instrument to assess sexual dysfunctional beliefs as vulnerability factors to sexual problems. Sexual and Relationship Therapy, 18(2), 171-204.

Ohrt, T., \& Thorell, L-H. (1998). Dysfunctional Attitude Scale (DAS). Psychometrics and norms of the Swedish version. Scandinavian Journal of Behaviour Therapy, 27(3), 105-113.

Power, M. J., Katz, R., McGuffin, P., Duggan, C. F., Lam, D., \& Beck, A. T. (1994). The Dysfunctional Attitude Scale (DAS). Journal of Research in Personality, 28(3), 263-276.

Reise, S. P., Moore, T. N., \& Haviland, M. G. (2010). Bifactor models and rotations: Exploring the extent to which multidimensional data yield univocal scale scores. Journal of Personality Assessment, 92, 544-559.

Reise, S. P., Scheines, R., Widaman, K. F., \& Haviland, M. G. (2013). Multidimensionality and structural coefficient bias in structural equation modeling: A bifactor perspective. Educational and Psychological Measurement, 73(1), 5-26.

Rude, S. S., Chrisman, J. G., Burton Denmark, A., \& Maestas, K. L. (2012). Expression of direct anger and hostility predict depression symptoms in formerly depressed women. Canadian Journal of Behavioural Science, 44(3), 200-209.

Ruiz, F. J., Suárez-Falcón, J. C., Barón-Rincón, D., Barrera-Acevedo, A., Martínez-Sánchez, A., \& Pena, A. (2015a). Factor structure and psychometric properties of the Dysfunctional Attitude Scale Revised in Colombian undergraduates. Revista Latinoamericana de Psicología, $48,81-87$.

Ruiz, F. J., Suárez-Falcón, J. C., Odriozola-González, P., Barbero-Rubio, A., López-López, J. C., Eisenbeck, N., et al. (2015b). Factor structure and psychometric properties of the Spanish version of the Dysfunctional Attitude Scale-Revised. Behavioural Psychology, 23(2), 27-303.

Sahin, N. H., \& Sahin, N. (1992). How dysfunctional are dysfunctional attitudes in another culture? British Journal of Medical Psychology, 65, 17-26.

Scher, D. C., Ingram, R. E., \& Segal, Z. C. (2005). Cognitive reactivity and vulnerability: Empirical evaluation of construct activation and cognitive diatheses in unipolar depression. Clinical Psychology Review, 25, 487-510.

Scotte, J. W. (1995). The relationship between premorbid neuroticism, cognitive dysfunction and persistence of depression. Journal of Affective Disorders, 33, 167-179. 
Senormanci, Ö., Yilmaz, A. E., Saracli, Ö., Atasoy, N., Senormanci, G., \& Atik, L. (2014). The mediator role of ruminative thinking style in the relationship between dysfunctional attitudes and depression. Comprehensive Psychiatry, 55, 1556-1560.

Tajima, M., Akiyama, T., Numa, H., Kawamura, Y., Okada, Y., Sakai, Y., et al. (2007). Reliability and validity of the Japanese version of the 24-item Dysfunctional Attitude Scale. Acta Neuropsychiatrica, 19, 362-367

Thase, M. E., \& Simons, A. D. (1992) Relapse after cognitive behavior therapy of depression. Potential implications for longer courses of treatment. American Journal of Psychiatry, 149, 1046-1052.

Theasdal, J. D., \& Dent, J. (1987). Cognitive vulnerability to depression. British Journal of Clinical Psychology, 26, 113-126.

Timmerman, M. E., \& Lorenzo-Seva, U. (2011). Dimensionality assessment of ordered polytomous items with parallel analysis. Psychological Methods, 16(2), 209-220.

Tringer, L. (2007). A gyógyító beszélgetés. Budapest: Medicina

Vosylis, R., Zukauskiene, R., \& Malinauskiene, O. (2012). Comparison of internet based versus paper-and-pencil administered assessment of positive development indicators in adolescent's sample. Psychology, 45, 7-21.

Weissman, A. N. (1979). Assessing depressogenic attitudes: A validation study. Unpublished thesis. Philadelphia, PA: University of Pennsylvania. Retrieved from: https:/ / repository. upenn.edu/cgi/viewcontent.cgi?article=2994\&context=edissertations 19.09.2019.

Weissman, A. N., \& Beck, A. T. (1978). Development and validation of the dysfunctional attitude scale: a preliminary investigation. Proceedings of the Annual Meeting of the American Educational Research Association, Toronto, 27-31 March 1978, 1-13.

World Health Organization. (2004). ICD-10: international statistical classification of diseases and related health problems: Tenth revision ( $2^{\text {nd }}$ ed.). World Health Organization

\section{Acknowledgements}

The study was supported by the Center of Excellence in High Education program of the Ministry of Innovation and Technology in the field of Neurology at Semmelweis University (FIKP) and a grant of Károli Gáspár University of the Reformed Church (Grant nu.: 20655B800 'Personality and Health Psychology' and 20643B800 'Person- and Familyoriented Health Sciences).

\section{Authors contribution}

Dóra Perczel-Forintos: developing idea, assuring the availability of clinical sample, critical reading of the paper. Barbara Kulig: data collection, writing the paper, literature review. Veronika Mészáros: writing the paper, literature review, interpreting results. Dóra AntalUram: data collection, literature review. Sándor Rózsa: statistical analyses, developing idea, interpreting results.

\section{Conflict of interest}

The authors declare that they have no conflict of interest. 


\section{Appendix: Diszfunkcionális Attitúd Skála (DAS-14)}

Kérem, karikázzon be 1-tól 5-ig egy számjegyet minden állítás mellett. 5-öt ha teljesen egyetért, 4-et ha kissé egyetért, 3-at ha bizonytalan, 2-t ha kissé nem ért egyet, 1-et ha egyáltalán nem ért egyet.

\begin{tabular}{|c|c|c|c|c|c|}
\hline & $\begin{array}{l}\text { Egyáltalán } \\
\text { nem értek } \\
\text { egyet }\end{array}$ & \begin{tabular}{c|} 
Kissé \\
nem értek \\
egyet
\end{tabular} & $\begin{array}{l}\text { Bizony- } \\
\text { talan }\end{array}$ & $\begin{array}{l}\text { Kissé } \\
\text { egyet- } \\
\text { értek }\end{array}$ & $\begin{array}{c}\text { Teljesen } \\
\text { egyet- } \\
\text { értek }\end{array}$ \\
\hline $\begin{array}{l}\text { 1. Nem lehetek boldog, } \\
\text { ha nem szeret valaki. }\end{array}$ & 1 & 2 & 3 & 4 & 5 \\
\hline $\begin{array}{l}\text { 2. Azok az emberek, } \\
\text { akiknek jó ötleteik vannak, } \\
\text { értékesebbek, mint } \\
\text { akiknek nincs. }\end{array}$ & 1 & 2 & 3 & 4 & 5 \\
\hline $\begin{array}{l}\text { 3. Ha meg vagyok győződve } \\
\text { arról, hogy jár nekem } \\
\text { valami, jogosan várhatom } \\
\text { el, hogy meg is kapjam. }\end{array}$ & 1 & 2 & 3 & 4 & 5 \\
\hline $\begin{array}{l}\text { 4. Ha mások nem szeretnek, } \\
\text { kevésbé vagyok boldog. }\end{array}$ & 1 & 2 & 3 & 4 & 5 \\
\hline $\begin{array}{l}\text { 5. Ha nem dologozom } \\
\text { olyan jól, mint mások, } \\
\text { kevesebbet érek. }\end{array}$ & 1 & 2 & 3 & 4 & 5 \\
\hline $\begin{array}{l}\text { 6. Természetes, hogy } \\
\text { az ember csalódottnak } \\
\text { érzi magát, ha akadályba } \\
\text { ütközik, hogy elérje, } \\
\text { amit akar. }\end{array}$ & 1 & 2 & 3 & 4 & 5 \\
\hline $\begin{array}{l}\text { 7. Ha azok az emberek, } \\
\text { akikkel törődöm, } \\
\text { visszautasítanak, valamit } \\
\text { rosszul csinálok. }\end{array}$ & 1 & 2 & 3 & 4 & 5 \\
\hline $\begin{array}{l}\text { 8. Ha sikertelen vagyok } \\
\text { a munkámban, sikertelen } \\
\text { ember vagyok. }\end{array}$ & 1 & 2 & 3 & 4 & 5 \\
\hline $\begin{array}{l}\text { 9. Ha mások igényeit } \\
\text { a magamé elé helyezem, } \\
\text { nekik is segíteniük kell. }\end{array}$ & 1 & 2 & 3 & 4 & 5 \\
\hline $\begin{array}{l}\text { 10. Másoktól elkülönülten élni } \\
\text { boldogtalansághoz vezet. }\end{array}$ & 1 & 2 & 3 & 4 & 5 \\
\hline
\end{tabular}




\begin{tabular}{|c|c|c|c|c|c|}
\hline & $\begin{array}{c}\text { Egyáltalán } \\
\text { nem értek } \\
\text { egyet }\end{array}$ & $\begin{array}{c}\text { Kissé } \\
\text { nem értek } \\
\text { egyet }\end{array}$ & $\begin{array}{c}\text { Bizony- } \\
\text { talan }\end{array}$ & $\begin{array}{c}\text { Kissé } \\
\text { egyet- } \\
\text { értek }\end{array}$ & $\begin{array}{c}\text { Teljesen } \\
\text { egyet- } \\
\text { értek }\end{array}$ \\
\hline $\begin{array}{c}\text { 11. Ha valamit nem tudok jól } \\
\text { megcsinálni, egyáltalán } \\
\text { nincs értelme belekezdeni. }\end{array}$ & 1 & 2 & 3 & 4 & 5 \\
\hline $\begin{array}{c}\text { 12. Ha jó férj/feleség vagyok, } \\
\text { házastársamnak szeretnie } \\
\text { kell engem. }\end{array}$ & 1 & 2 & 3 & 4 & 5 \\
\hline $\begin{array}{c}\text { 13. Ha nem állítom magam elé } \\
\text { a legmagasabb mércét, } \\
\text { másodrendú ember leszek. }\end{array}$ & 1 & 2 & 3 & 4 & 5 \\
\hline $\begin{array}{c}\text { 14. Ha valakinek jót teszek, } \\
\text { remélhetem, hogy } \\
\text { tekintettel lesz rám és } \\
\text { éppen olyan jól fog bánni } \\
\text { velem, mint én vele. }\end{array}$ & 1 & 2 & 3 & 4 & 5 \\
\hline
\end{tabular}

\title{
Kiértékelés:
}

A DAS-14 faktorstruktúrájában három alskála szerepel, de a kérdőíven elért összpontszám is értelmezhető önmagában. Nincsenek fordított tételek.

Az alskálák képzése a tételek összeadásával történik.

Szeretettségigény/Dependencia alskála: 1., 4., 7. és 10. tételek

Perfekcionizmus/Teljesítményigény alskála: 2., 5., 8., 11. és 13. tételek

Elvárások alskála: 3., 6., 9., 12. és 14. tételek

\section{A Diszfunkcionális Attitúd Skála rövidített változatának (DAS14) pszichometriai jellemzóinek vizsgálata nagy klinikai mintán}

\author{
PERCZEL-FORINTOSDÓRA - MÉSZÁROS VERONIKA - \\ KULIG BARBARA - ANTAL-URAM DÓRA - RÓZSA SÁNDOR
}

Elméleti háttér: A Diszfunkcionális Attitúd Skála (DAS) egy olyan pszichológiai kérdőíves eljárás, amely azon diszfunkcionális hiedelmek mérésére alkalmas, amelyek hozzájárulnak a depresszív tünetek kialakulásához és fennmaradásához. Annak ellenére, hogy már számos változata létezik és elsődleges használati területét a klinikai populáció jelenti, pszichometriai mutatóit klinikai mintán a kutatások szúk köre vizsgálta. Cél: Jelen tanulmány célja a DAS aktualizálása, rövidítése, megbízhatóságának és validitásának vizsgálata. Módszer: Keresztmetszeti kérdőíves vizsgálatunk keretében egészséges serdülő $(n=195)$ és felnőtt $(n=270)$ minta mellett heterogén klinikai mintát $(n=1077)$ alkalmaztunk. 
Eredmények: A parallelelemzés és a feltáró faktoranalízis eredményei a bifaktoros struktúrát igazolják. A 14 itemre egy általános és három alfaktor (Dependencia, Perfekcionizmus és Elvárások) illeszthető $\left(\chi^{2}=157,26, \mathrm{DF}=63, p<0.001 ; \mathrm{CFI}=0,970 ; \mathrm{TLI}=0,957\right.$; RMSEA = 0,036, RMSEA 90\% CI = 0.029-0.044). A skála konvergens validitását a Beck Depresszió Kérdőívvel való korrelációja alátámasztja $(r=0,36 ; p<0,001)$. Konklúzió: A DAS pszichometriai vizsgálatai közül ez idáig alkalmazott legnagyobb klinikai elemszámú vizsgálatát mutatja be a tanulmány. Az eredmények alapján a DAS rövidített változata, a DAS-14 megfelelő pszichometriai tulajdonságokkal rendelkezik alkalmazható a hangulatzavarok diagnosztikájában.

Kulcsszavak: Diszfunkcionális Attitúd Skála, DAS-14, rövidített változat, nagy klinikai minta, bifaktoros elemzés, validitás

This is an open-access article distributed under the terms of the Creative Commons Attribution 4.0 International License (https://creativecommons.org/licenses/by/4.0/), which permits unrestricted use, distribution, and reproduction in any medium, provided the original author and source are credited, a link to the CC License is provided, and changes - if any - are indicated. (SID_1) 